\title{
The Pitfalls of Ethnolinguistic-Based Federal Experiment in Ethiopia
}

\author{
B.D. Gardachew, G.M. Kefale, G.A. Kumie \\ Bahir Dar University \\ Bahir Dar, Ethiopia
}

\begin{abstract}
In 1991, when Tigray People's Liberation Front (TPLF) became a leading party within the Ethiopian People's Revolutionary Democratic Front (EPRDF), Ethiopia introduced a system of ethnic-based federalism, which had never been practiced in the political history of the state before. The recognition of Ethiopian ethnic diversity became one of the country's fundamental principles, with the federal system largely consisting of ethnic-based territorial units. Since its inception, Ethiopia's ethnic federalism has been the subject of heated debate among various political organizations in the country, as well as among observers and scholars both in and outside the country. The key objective of this paper is to appraise the pitfalls of ethnic-based federalism in Ethiopia, which has been functioning in the country for more than two and half decades. The authors believe ethnic-based federalism to be a political arrangement that succeeds to maintain balance of centrifugal and centripetal forces. They see it as an appropriate and viable strategy for a sustainable nation-building effort in the context of Ethiopia's ethnic diversity. At the same time, the authors observe that in the case with ethnicity-based political arrangements, unless they are implemented with maximum care, the risk outweighs the benefit. When a state like Ethiopia, which had been highly centralized for many years, is trying to experiment with a seemingly federal arrangement, the equilibrium of diversity and unity should be maintained. If the political environment focuses primarily on diversity and ignores shared values and common identity, it leaves room for the elites to manipulate the differences and pursue their own parochial political interests, which would eventually serve against the public benefit. The pioneers of Ethiopia's ethnic federalism believe that the contemporary ethnolinguistic-based federal arrangement is a panacea for problems related to identity politics. However, the authors argue that, from a practical perspective, for the past two and half decades (probably in the future too, unless re-designed) ethnic federalism in Ethiopia has been highly politicized (manipulated by political dealers promoting their own selfish interests).
\end{abstract}

Keywords: ethnic federalism, pseudo-federalism, TPLF/EPRDF, politicization of ethnicity.

\section{Background}

The modern Ethiopian state was formed in the middle of $19^{\text {th }}$ century (during the era of the "scramble" for Africa) through unification of the major areas of the

(c) Gardachew B.D., Kefale G.M., Kumie G.A., 2019.

(c) (i) This work is licensed under a Creative Commons Attribution 4.0 International License https://creativecommons.org/licenses/by/4.0/ 
northern part and the expansion of territories to the south $[1 ; 2 ; 3]$. Since Tewodros II had initiated the policies of modernization and centralization, almost all of his successors (Yohannes IV, Menelik II and Haile Selassie) followed these policies, albeit with different levels of zeal and dynamism [4].

The military regime, replacing the imperial regime, is credited for its radical land reform, which restored land ownership to the peasants in the southern parts of the country, who had been subjugated during the empire's unification project. However, the regime did not affect the excessive centralization of the political system, and the dictatorship continued to marginalize the country's ethnic groups [5].

The 'national question', which was began to arise during the imperial period, continued to gain currency and subsequently became one of the key points on the country's political agenda. Though, the 'Derg' had attempted to answer the 'national question' on its own terms, none of the efforts had satisfied the demands of the groups whose organization was based on ethnic principles. In a short while, contrary to expectations of various scholars and students who stood at the origin of the revolution, the 'Derg' adopted a very harsh measure against any political dissent including ethno-regional movements $[4 ; 6]$.

According to Kidane [5], as the military regime continued to use force to suppress rancour, ethnic rebellions intensified in many parts of the country. As is suggested by Semahegn [6] and Muhabie [4], the use of force and the complete closure of political space by the 'Derg' reinforced ethno-regional movements, namely the Tigrean People Liberation Front (TPLF), Eritrean People's Liberation Front (EPLF) and the Oromo Liberation Front (OLF). Finally, ethno-nationalist groups allied with other forces and overthrew the military regime replacing it with TPLF, which led to the formation of the Ethiopian People's Revolutionary Democratic Front (EPRDF) in 1991. EPLF took control of Eritrea, while TPLF controlled Ethiopia under the cover of EPRDF. After TPLF/EPRDF came to power in 1991, the so-called ethnic-based federalism was established and is still in practice in Ethiopia. Hence, the main objective of this paper is to critically appraise the failure and success of Ethiopia's ethnolinguistic-based federal structure. Qualitative approach is used as the main assessment method in the research. Qualitative method attempts to get an understanding of how things are in the social world, why they are that way, and why people act the way they do [7]. The data used in the research have been derived mostly from secondary sources (legal proclamations, articles, journals and publications), relevant to the subject matter. For each of the sources used, references have been provided.

\section{The genesis of ethnic consciousness in Ethiopia}

Despite occasional protests against the rule of Ethiopia's central government in different parts of the country, the 'national question' had never been at top of mind before, even in the first three decades of the imperial regime. According to Endalamaw [8], the understanding of nationality and ethnicity came into Ethiopian political vocabulary in the 1960s (see also the 1968 TPLF manifesto). The "na- 
tional question' as such was introduced and brought into focus by the Ethiopian Student Movement (ESM), which at the time was actively disseminating the ideologies and principles of Marxism-Leninism within the country and abroad [9].

Van der Beken [10] also notes that although previous rebel movements in different parts of the country undoubtedly influenced the critical stance of the students, the impact of Marxist-Leninist ideas was crucial. The 'issue of nationalities' brought up by Marxist-Leninist ideology was applied to the realities of Ethiopian society. The Ethiopian student movement, along with other similarlyminded groups, was strongly convinced of the applicability of Marxist-Leninist ideas about nationality to Ethiopian reality. It was their belief that the Ethiopian problem could be addressed more effectively through the Marxist-Leninist framework.

In his publication, 'Marxism and the National Question', Stalin recognized the right to self-determination of nations, which he described as follows: "that only the nation itself has the right to determine its destiny, that no one has the right to forcibly interfere in the life of the nation, destroy its schools and other institutions, violate its habits and customs, repress its language, or curtail its rights". Moreover, according to Stalin, as well as Lenin, the right to self-determination even involved the right to secession. Both stated that these ideas should be promoted and applied in regard to every nation [10]. Regrettably, at the time the Marxist-Leninist ideas, introduced from abroad, were not adopted to the Ethiopian socio-cultural realities of the time.

Following this, numerous groups, organized on the basis of ethnicity, ventilated a lot of identity-related issues. For instance, the 1968 TPLF Manifesto openly recognized the existence of national oppression. According to the Manifesto, the 'oppressing' nation (Amhara) politically and economically marginalized, as well as culturally and linguistically dominated various minority nationalities [8]. An article by Wallelign Mekonnen, inspired by the Marxist-Leninist position of social justice and national and ethnic equality, poured oil on flames:

"Is it not simply Amhara and to a certain extent Amhara-Tigre supremacy? Ask anybody what Ethiopian culture is. Ask anybody what the Ethiopian language is. Ask anybody what Ethiopian religion is. Ask anybody what the national dress is. It is either Amhara-Amhara Tigray! To be a 'genuine Ethiopian' one has to speak Amharic, to listen to Amharic music, to accept the Amhara-Tigre religion, Orthodox Christianity, and to wear the Amhara-Tigre shemma in international conference. In the same case, to be an 'Ethiopian', you will even have to change your name. In short, to be an Ethiopian, you will have to wear an Amhara mask" [11].

The ideological antecedents of contemporary ethnic federalism can be traced back to Marxist-Leninist ideology and its conception of "the national question". To an extent, the project was shaped after the example of the USSR and Yugoslavia. Once the ideology of Marxism-Leninism was introduced to Ethiopia by the Ethiopian Student Movement, the "national question" became a burning one. In 1991, when TPLF, in alliance with other Liberation Fronts, became a leading par- 
ty within EPRDF, the doctrine of Marxism-Leninism constituted the basis for a new federal state structure. Thus, ideological orientation and political necessity relied on ethnic federalism as on a framework for resolving issues of ethnic and regional autonomy. Ethnic federalism was meant to guarantee the right to selfdetermination within the Ethiopian nation as a whole [12].

There are major similarities between the visions of the Ethiopian Students Movement of the time and the current state building strategy. In the present FDRE constitution, ethnic diversity is recognized and used as a founding element of nation building. Moreover, the constitution further supports ESM ideas by granting a right to secession to Ethiopia's 'nations' [10]. It is therefore fair to assert that there is a direct correlation between the approach towards the ethnic issue adopted by the Ethiopian students at the end of the 1960s and the modern state building strategy in Ethiopia, which is explicitly expressed in the present constitution.

\section{Contradictory views on ethnic federalism in Ethiopia}

Since the introduction of ethnic federalism in Ethiopia, it has been - and most likely will continue to be - a subject of heated debate in political discourse both inside and outside the country. Among academics, there is no consensus in regard to the current state arrangement in Ethiopia. In this section, we are going to examine the existing contradictory views on the relevance of ethical federalism as a viable political system.

The pioneers and advocates of the new federal arrangement believe that the introduction of ethnic federalism in Ethiopia helped to embrace the country's diversity. The previous political regimes were highly centralized and focused on unity, not giving much attention to ethnic divergences. According to some scholars, ethnic federalism also contributes to state building and national consensus, as it promotes self-rule and shared rule, the sense of oneness amidst multiformity, and therefore the chance of conflict among ethnic groups is minimal [13-15].

Supporters of ethnic federalism point out that it has maintained the unity of the Ethiopian peoples and the territorial integrity of the state, while providing full recognition of the principle of ethnic equality. From this perspective, for Ethiopia, a country with an impressive ethnic diversity, a federal arrangement of this kind is an appropriate solution. Ethiopia's main problem for a long time had been national oppression, and according to the proponents of ethnical federalism, the current state structure is able to keep the nation's autocracy under control and manage inter-ethnic tensions within the country [14; 15].

According to Abbink [16], opponents of ethnic federalism assert that EPRDF opted for the current system for the purpose of "institutionalizing and facilitating 'divide and rule' and ensuring the ruling parties position". Scholars who view ethnic federalism with suspicion tend to believe that from the very outset, TPLF (which at the time represented only a tiny percentage of the population) was striving to design a mechanism to secure its position and power. One way of doing so 
was to transfer the country into ethnically defined regional states and create ethnically defined parties under its control $[17 ; 18]$.

Accordingly, the fundamental reason behind the establishment of ethnic federalism along ethnic lines is a strategy calculated by the ruling regime to consolidate the dominant party's rule. Therefore, the current ethnicity-based political arrangement may create conditions for its politicization and trigger a split-up in national consciousness, producing multiple ethnic groupings at the expense of collective sense of belonging, common purpose and shared identity.

One of the essential features of the Ethiopian ethnic federal system is that it allows secession for any ethnic unit as long as the constitutional requirements are met $^{1}$. However, according to Alem [12] and Endalamaw [8], the secession clause is one of the most controversial issues in public discourse in Ethiopia and its diaspora communities today. Opponents of ethnic federalism fear that it invites ethnic conflict and risks state disintegration. The Ethiopian state, they worry, may face the same fate as the USSR and Yugoslavia. Others, although being optimistic and supportive of the ethnic federal constitution per se, still doubt the government's real commitment to self-determination and claim that so far the underlying constitutional principles have not been seriously put into practice.

To many critics, the federal state is a de facto one-party state in which ethnic organizations are mere satellites of one ethnic organization, the TPLF, which is the leading unit in the ruling coalition, the EPRDF. Lastly, those who consider Ethiopia to be a colonial empire see the federal exercise as yet another colonial trick, and advocate "decolonization".

Many scholars express their concern that Ethiopia's constitutionalized version of ethnic federalism, with its focus on nations, nationalities, and peoples, its statebuilding along purely ethnic lines, and its use of ethnicity as the key component for political participation will lead to greater instability, more ethnic conflict, and the proliferation of secessionist movements. Ethnic federalism intentionally entrenches ethno-cultural differences and simultaneously creates and reinforces "primordial" ethnic divisions that may not be stable or may even pre-exist the labeling [17-21]. Consequently, the concretization of ethnic identities will likely hinder the ability of different groups to integrate or develop national identities, and may lead to ethnic conflict and the eventual dissolution of the nation.

Those who oppose ethnic federalism argue that the current Ethiopian Constitution does not solve but actually exacerbates the problem of tribalism [16]. The proponents of the current system, who believe in Ethiopia's strong national identity, still worry that this identity may erode, as individuals are encouraged to think of themselves as a member of a specific ethnic group or as Regional States, rather than an Ethiopian citizen [18; 20;22].

\footnotetext{
${ }^{1}$ See the 1995 FDRE Constitution, article 39 (1), this secession clause gives unconditional right to ethnic groups to secede from the federation as long as the constitutional procedures are followed.
} 
Stressing ethnic differences through the Constitution and political process instead of letting them fade "encourages aggressive ethnic identification and separatism and exacerbates ethnic distrust and social discord". It also incentivizes each state to pursue its own parochial interests strictly defined by ethnic lines $[14 ; 20$; 22-24].

\section{The pitfalls of ethnic federalism in Ethiopia}

Politicization of Ethnicity. As stated in the introductory section, this purpose of this paper is to examine the shortcomings of Ethiopia's ethnic-based federalism. To many scholars in and outside the country, one of the main drawbacks of the Ethiopian federal arrangement is the use of ethnicity for political purposes. According to Muhabie [4], since the adoption of the new political arrangement in 1991, ethnicity has become the primary means of political mobilization in Ethiopia. Most often political representation is organized on ethnic grounds, and consequently groups are encouraged to claim "ethnic rights" at the expense of others [25].

The constitutionally enshrined self-determination right incites political elites to control kebeles, districts and regions in order to have a share of resources channeled from the federal to the local level. Local politicians and party officials from all ethnic groups, both government and opposition, have at times coaxed their followers into initiating conflict with competing groups [8; 26]. It is therefore evident that political elites at different levels of administration have used ethnic identities to their advantage while pursuing their own self-serving interests, which is contrary to the fundamental principle of what the federal arrangement aspires to achieve.

In contemporary Ethiopia, the number of ethnic denominations and classifications has grown, inspired more by political, social and economic interests rather than primordial sentiments [8]. Although national, cultural and social formations are basic foundations for fostering solidarity and political invigoration, ethnic perception and mobilization have emerged due to social, economic and political reasons more so than before. This increased degree of "ethnic consciousness and ethnic mobilization" has been attributed to the activities of political elites, which have been manipulating the larger population's ethnic affiliation to advance their self-interests $[16 ; 27 ; 28]$. Thus, ethnic federalism has become a fertile ground for political elites' lucre-seeking endeavors.

According to Kidane [5], the contemporary Ethiopian ethnic essentialism has emerged due to political justification more than before. Lack of fair management of identity relations and moderation of inter-identity inequalities and an instrumental sense of ethnicity strengthens politicization of ethnicity in the Ethiopian politics. For Assefa [15] this political polarization can instigate organization of conscious ethnic groups at the expense of the community and hinder democratization for nation building. 
According to Endalamaw [8] federating a diversified state, which Ethiopia is a typical example; by strict ethnic lines may not be practical or beneficial. What results is the utilization of ethnicity. If ethnicity is utilized as a source of resource and power, it has a prospective to create an opportunity to engage in a political polarization. The politicization of ethnicity for one's own advantage is also a clear violation of the very foundation of the constitution.

The 1995 FDRE Constitution under its preamble explicitly specifies that the common destiny of nations, nationalities and peoples of Ethiopia "can best be served by rectifying historically unjust relationships and by further promoting their shared interests". However, according to Assefa [15] there is a huge gap between the promise of the constitution and the reality on the ground. From this, one can infer that political elites have been committed to politicization of ethnicity in the name of the so-called practice of 'rectifying historically unjust relationships between ethnic groups'. This paper also argues that, the constitution itself has politicized ethnicity specifically in its preamble section.

Pseudo-federalism. The Ethiopian ethnic-based federal arrangement is criticized for its failure to decentralize genuine power to the federating units in a practical sense. In this regard, Kidane's empirical evidence [25] is helpful to understand whether Ethiopia's state structure is based on genuine decentralization of power or not. The scholar has conducted many studies on federalism and he came up with tangible data about the practical realities of the Ethiopian ethnic-based political arrangement.

According to Kidane [25], there are a number of facts demonstrating that the Ethiopian government has failed to devolve real power to the regions and bring about genuine decentralization. The main indicator of the failure is the extreme financial dependence of the regional governments (with the exception of Addis Ababa's municipal administration) on the central government, which monopolized most of the revenue-generating resources and assumed a strong redistributive role (see also [29]). As Kidane fairly notes, the excessive financial reliance of regional states on the central government undermines the goal of political decentralization; and more importantly, it deprives the regional governments of the ability to control their development process.

Many scholars concur that, for a long time, the Ethiopian political system has been dominated by TPLF, one of the founding members of the Ethiopian People's Revolutionary Democratic Front (see for example, $[4 ; 8 ; 10 ; 12 ; 25 ; 30 ; 31 ; 32]$. Kidane [25] believes that in a multiethnic country, especially in a country with antagonistic relations between the state and ethnic groups, a successful strategy of state-building requires genuine decentralization and ethnic neutrality of the state at its center, both in essence and in appearance. The scholar questions the neutrality of the TPLF/EPRDF leadership and recommends a different political arrangement in the form of an ethnically neutral state.

Nowadays, TPLF officials occupy key decision-making positions in the Ethiopian government. As correctly stated by Kidane, such disproportionate political 
influence has made the government neither truly neutral nor representative of all ethnic groups in the country. The current state of affairs in Ethiopian politics has come down to a situation where the founding members of EPRDF, such as OPDO and ANDM, are complaining about the political dominance of TPLF ${ }^{2}$. In numerous public rallies organized against the ruling regime (TPLF/EPRDF), the protesters cried out against TPLF's political and economic supremacy ${ }^{3}$.

According to Keller [33], major policies and implementation strategies in Ethiopia are currently highly centralized, with regional states replicating the central administrative decisions. Similarly, for Teshome and Záhoř́k [34], administration in Ethiopia is federal only in a structural sense. Siraw [31] supports their argument, stating that the federal system is nominal, with central control and topdown rule precluding local initiative and autonomy.

In concurrence with the above-mentioned authors, Frank [35] confirms that the Ethiopian federal government has been exercising increasing control over the autonomous regions, thus excluding locals from political participation. Such extensive control, according to Frank, may have been necessary for state security; however, it is further eroding the trust in the government and alienating local people from politics. Hence, it is fair to argue that a federation cannot be genuine if it is a result of coercion from above (the center). Such type of power hierarchy raises doubts about the credibility of the central government.

Another popular political rhetoric states that Ethiopia's political system remains highly centralized and dominated by a single ethnic identity, while the government uses the system in order to "divide and rule" rather than encourage the regional governments' self-authority [16; 36]. Kidane [5] argues that contemporary Ethiopia experiences a continued centralization by TPLF, which keeps creating ethnic-based satellite parties with the purpose of controlling the regional governments. Such ancillary parties have become puppets, with the help of which the EPRDF exercises an indirect rule over the whole country.

\section{Concluding remarks}

Since the beginning of Ethiopia's modern history and up until the downfall of the military regime, the state had pursued a centralized (close to unitary) type of political structure. With the fall of the the Derg rule, the victorious coalition TPLF/EPRDF assumed political power and adopted a new type of federal arrangement, novel and radical in its essence. The ideological basis of the contem-

\footnotetext{
${ }^{2}$ Out of four political parties that initially comprised EPRDF (ANDM, OPDO, SEPDM and TPLF), three parties were unable to exercise their political power at the federal level. The Tigrayan People's Liberation Front (TPLF), a political party that led the way in the creation of the EPRDF, has established a dominating position and is controlling the security apparatus of the state.

${ }^{3}$ For example, on July 31, 2016 thousands of protesters, who demonstrated in Gondar, a major city in the Amhara region, and in neighboring localities, demanded an end to TPLF rule over Ethiopia.
} 
porary ethnic federalism project can be traced back to the Marxist-Leninist doctrine. Ever since the adoption of the new federal system, scholars' opinions have been divided over its normative and practical significance for the state. The given paper advocates that, provided it is implemented in accordance with its initial ideas, the benefits of ethnical federalism outweigh its risks; however, maximum care should be taken to avoid manipulation by political entrepreneurs. The existing literature and data confirmed that multiple Ethiopian ethnicities have been used by political elites for selfish gains. As is fairly argued by Kidane [5], contemporary Ethiopian politics lacks genuine decentralization of power and experiences continued concentration of control by TPLF through its ethnic-based satellite parties. As is noted by Mohammed Hassen [36], regrettably, Ethiopia has once again missed a golden opportunity to realize a workable strategy of state building.

\section{References}

[1] Pankhurst R. Economic History of Ethiopia, 1800-1935. Addis Ababa: Haile Sellassie I University Press; 1968.772 p.

[2] Teshale T. The Making of Modern Ethiopia: 1896-1974. The Red Sea Press; 1995. 246 p.

[3] Bahiru Z. A History of Modern Ethiopia, 1855-1974. Ohio Univ Press; 1991. 244 p.

[4] Muhabie M. Ethnic Federalism: A Means for Managing or a Triggering Factor for Ethnic Conflicts in Ethiopia. Social Sciences. 2015; 4 (4): 94-105.

[5] Kidane M. Africa's Intrastate Conflicts: Relevance and Limitation of Diplomacy. African Issues. 2003; 32 (1): 25-39. DOI: 10.1017/S1548450500006594

[6] Semahegn A. The dilemma of Adopting Ethnic Federal System in Africa in Light of the Perspectives from Ethiopian Experience. Journal of African Studies and Development. 2012; 4 (7): 168-175.

[7] Marshall C., Rossman G.B. The "What" of the Study: Building the Conceptual Framework. Designing Qualitative Research. 1999; 3 (3): 21-54.

[8] Endalamaw C. Ethnic Federalism and Nation Building in Development: The Case of Ethiopia. Doctoral dissertation. Addis Ababa University; 2015.

[9] Merera G. Contradictory Interpretation of Ethiopian History. Ethnic Federalism: The Ethiopian Experience in Comparative Perspective. Addis Ababa: Addis Ababa University Press; 2006.

[10] Van der Beken C. Federalism and the Accommodation of Ethnic Diversity: The Case of Ethiopia. Third European Conference on African Studies. 2009: 1-21.

[11] Wallelign M. On the Question of Nationalities in Ethiopia. 17.11.1969. Available from: https://www.marxists.org/history/erol/ethiopia/nationalities.pdf. Accessed: 10.01.2019.

[12] Alem H. Ethnic Federalism in Ethiopia: Background, Present Conditions and Future Prospects. Paper Submitted to the Second EAF International Symposium on Contemporary Development Issues in Ethiopia July 11-12, 2003. 33 p.

[13] Watts R.L., Rovinsky D.J. Comparing Federal Systems in the 1990s. The American Review of Canadian Studies. 1999; 29 (2): 367.

[14] Alemante G.S. Ethnic Federalism: Its Promise and Pitfalls for Africa. Yale Journal of International Law. 2003; 28: 51-107.

[15] Assefa F. Ethiopia's Experiment in Accommodating Diversity: 20 Years' Balance Sheet. Regional \& Federal Studies. 2012; 22 (4); 435-473.

[16] Abbink J. Ethnicity and Constitutionalism in Contemporary Ethiopia. Journal of African Law. 1997; 41 (2): 159-174. 
[17] Abbink J. Ethnicity and Conflict Generation in Ethiopia: Some Problems and Prospects of Ethno-regional Federalism. Journal of Contemporary African Studies. 2006; 24 (3): 389-413.

[18] Legesse T. Ethnic Federalism and Conflict in Ethiopia: What Lessons Can Other Jurisdictions Draw? African Journal of International and Comparative Law. 2015; 23 (3): 462-475.

[19] Ehrlich Ch.E. Ethnicity and Constitutional Reform the Case of Ethiopia. ILSA Journal of International \& Comparative Law. 1999; 6: 51-71.

[20] Aalen L. Ethnic Federalism and Self-determination for Nationalities in a Semi-authoritarian State: The Case of Ethiopia. International Journal on Minority and Group Rights. 2006; 13 (2-3): 243-261.

[21] Abebe D. Ethnic Federalism in Ethiopia: A Means to an End. 2017. Available from: https://www.law.uchicago.edu/files/Session\%20VI_Abebe.pdf. Accessed: 11.01.2019.

[22] Legesse T. Federalism as an Instrument for Unity and the Protection of Minorities: A Comparative Overview: Ethiopia, India and the US. Mizan Law Review. 2016; 10 (2): 265-295.

[23] Minasse H. The New Ethiopian Constitution: Its Impact upon Unity, Human Rights and Development. Suffolk Transnational Law Review. 1996; 20 : 1.

[24] Bereket H. Self-determination in Principle and Practice: The Ethiopian-Eritrean Experience. Columbian Human Rights Law Review. 1997; 29: 91.

[25] Kidane M. Ethiopia's Ethnic-based Federalism: 10 Years After. African Issues. 2001; 29 (12): $20-25$.

[26] Engineering Ethnic Conflict: The Toll of Ethiopia's Plantation Development on Suri People. The Oakland Institute. 2014.

[27] Berhanu G. Restructuring State and Society: Ethnic Federalism in Ethiopia. SPIRIT Doctoral Programme Series, Thesis No. 8. Denmark: Aalborg University; 2007.

[28] Bekalu T. Ethnic Federalism and Conflict in Ethiopia. African Journal on Conflict Resolution. 2017; 17 (2): 41-66.

[29] World Bank, Ethiopia: Review of Public Finances. Vol. 1. Report No. 18369-ET. 30.12.1998.

[30] Vaughan S. Ethnicity and Power in Ethiopia. PhD Thesis. The University of Edinburgh; 2003. $322 \mathrm{p}$.

[31] Siraw M. Weaknesses of Ethnic Federalism in Ethiopia. International Journal of Humanities and Social Science Invention. 2015; 4 (11): 49-54.

[32] Temesgen T. Ethnic Federal System in Ethiopia: Origin, Ideology and Paradoxes. International Journal of Political Science and Development. 2016; 4 (1): 1-15. DOI: 10.14662/IJPSD2016.004.

[33] Keller E.J. Ethnic Federalism and Democratization in Ethiopia. Horn of Africa. 2003; 21: 3043.

[34] Teshome W., Záhořík J. Federalism in Africa: The case of Ethnic-based Federalism in Ethiopia. International Journal of Human Sciences. 2008; 5 (2). Available from: https://www.jhumansciences.com/ojs/index.php/IJHS/article/view/506/311. Accessed: 10.01.2019.

[35] Frank M. Effects of Ethnic Federalism in Ethiopia. Holding Together or Splitting Apart? University of Toronto/University of Frieburg, Summer Institute Guadalajara. 2009.

[36] Ottaway M. Democratization and Ethnic Nationalism: African and Eastern European Experiences. Washington DC: Overseas Development Council; 1994. 85 p.

[37] Hassen M. Ethiopia: Missed Opportunities for Peaceful Democratic Process. State Building and Democratization in Africa: Faith, Hope, and Realities. Ed. by K. Mengisteab and C. Daddieh. Westport and London: Praeger; 1999: 233-260.

\section{Article history:}

The article was submitted on 15.07.2019.

The article was accepted on 07.11.2019. 


\title{
Подводные камни этнолингвистического федерального эксперимента в Эфиопии
}

\author{
Б.Д. Гардашью, Г.М. Кефале, Г.А. Кумие \\ Университет Бахр-Дар \\ Бахр-Дар, Эфиопия
}

\begin{abstract}
Аннотация. В 1991 г., когда Народный фронт освобождения Тыграй (НФОТ) стал ведущей партией в составе Революционно-демократического фронта эфиопских народов (РДФЭН), Эфиопия ввела систему этнического федерализма, которая никогда ранее не практиковалась в политической истории государства. Признание этнического многообразия Эфиопии стало одним из основополагающих принципов для страны, поскольку федеративная система в значительной степени состоит из этнических территориальных единиц. С момента своего создания этнический федерализм Эфиопии был предметом горячих дебатов среди различных политических организаций, наблюдателей и ученых как внутри страны, так и за ее пределами. Основная цель статьи - оценить «подводные камни» модели этнического федерализма в Эфиопии, которая действует уже более двух с половиной десятилетий. Авторы полагают, что этнический федерализм является политическим устройством, которое успешно поддерживает баланс центробежных и центростремительных сил в стране. Они рассматривают его как надлежащую и жизнеспособную стратегию для устойчивого национального строительства в контексте этнического разнообразия Эфиопии. В то же время авторы отмечают, что в случае, если политические договоренности на этнической основе не осуществляются с максимальной осторожностью, сопряженный с ними риск перевешивает выгоду. Если такое государство, как Эфиопия, которое в течение многих лет было сильно централизовано, пытается экспериментировать с федеративным устройством, то в стране должно поддерживаться равновесие разнообразия и единства. Если политическая среда фокусируется главным образом на разнообразии и игнорирует общие ценности и общую идентичность, она оставляет возможности для того, чтобы элиты манипулировали этническими различиями и преследовали свои собственные партикулярные политические интересы, что в итоге будет работать против общества. Основатели эфиопского этнического федерализма считают, что современное этнолингвистическое федеративное устройство является панацеей от проблем, связанных с политикой идентичности. Однако авторы статьи утверждают, что с практической точки зрения в течение последних двух с половиной десятилетий (вероятно, это продолжится и в будущем) этнический федерализм в Эфиопии был слишком политизирован силами, продвигающими собственные интересы.
\end{abstract}

Ключевые слова: этнический федерализм, псевдофедерализм, РДФЭН, политизация этничности.

\section{История статьи:}

Статья поступила в редакцию 15.07.2019.

Статья принята к публикации 07.11.2019.

\section{Информация об авторах:}

Гардашью Бевукету Дирес - преподаватель и исследователь департамента политологии и международных исследований университета Бахр-Дар (Эфиопия) (e-mail: bewuket23@gmail.com).

Кефале Гебеэху Менгеша - преподаватель и исследователь департамента социальной антропологии университета Бахр-Дар (Эфиопия) (e-mail: bduinfo@bdu.edu.et). 
Кумие Гетахун Антигегн - преподаватель и исследователь департамента политологии и международных исследований университета Бахр-Дар (Эфиопия) (ORCID ID: 0000-00028871-0757) (e-mail: getkumie@gmail.com).

\section{Information about the authors:}

Bewuketu Dires Gardachew - Lecturer and Researcher of the Department of Political Science and International Studies, Bahir Dar University (Ethiopia) (e-mail: bewuket23@gmail.com).

Gebeyehu Mengesha Kefale - Lecturer and Researcher of the Department of Social Anthropology, Bahir Dar University (Ethiopia) (e-mail: bduinfo@bdu.edu.et).

Getahun Kumie Antigegn - Lecturer and Researcher of the Department of Political Science and International Studies, Bahir Dar University (Ethiopia) (ORCID ID: 0000-0002-8871-0757) (e-mail: getkumie@gmail.com).

\section{Для цитирования:}

Gardachew B.D., Kefale G.M., Kumie G.A. The Pitfalls of Ethnolinguistic-Based Federal Experiment in Ethiopia // Вестник Российского университета дружбы народов. Серия: Политология. 2019. T. 21. № 4. C. 661-672. DOI: 10.22363/2313-1438-2019-21-4-661-672

\section{For citation:}

Gardachew B.D., Kefale G.M., Kumie G.A. The Pitfalls of Ethnolinguistic-Based Federal Experiment in Ethiopia. RUDN Journal of Political Science. 2019; 21 (4): 661-672. DOI: 10.22363/2313-1438-2019-21-4-661-672 